\title{
Emergency Contraception for French Adolescents: Is Free and Easy the Best?
}

\author{
Florence Taboulet* \\ Droit pharmaceutique et Économie de la santé, Université Toulouse III, France
}

Submission: April 15, 2018; Published: May 16, 2018

"Corresponding author: Florence Taboulet, Droit pharmaceutique et Économie de la santé, UMR 1027 Inserm, Université Toulouse III, 35 chemin des Maraîchers-31062 Toulouse cedex 09, France, Email: florence.taboulet@univ-tlse3.fr

Abstract

The free and anonymous dispensing of emergency contraceptive pills to minors in France derogates from classic rules of health security and does not guarantee appropriate use of this medication.

Keywords: Emergency contraception; Minors; Anonymous and free dispensation; Health security; Drug assessment; Health policy assessment

\section{Introduction}

Based on the premise that easy access to emergency contraception (EC) would make it possible for adolescents to avoid abortion, nearly 20 years ago France implemented an exception-to-the-rule policy, granting minors free and easy access to this "day-after" medication. Two products were marketed with this indication: levonorgestrel (LNG), 1 tablet of $1.5 \mathrm{mg}$, and ulipristal acetate, 1 tablet of $30 \mathrm{mg}$. The package leaflets for the former recommend exceptional usage and for the latter, occasional usage. After describing the context, we will discuss the impact of this decision .

\section{Unlimited and Free Supply}

In France, rules concerning dispensation of medicinal products are particularly numerous and demanding. They are felt to be necessary to promote health security and to guarantee the relevance of reimbursed pharmaceutical costs. How, then, can these rules be waived all the while guaranteeing appropriate use of drugs? Highlighting the five main exceptions offers insight into the question [1].

\section{Exemption from parental authority}

Both dispensation and covering costs of anonymous EC are handled unbeknownst to parents and are protected by professional confidentiality [2].

\section{Absence of a prescribing physician}

The two medicinal products involved, subject to regulation of harmful substances constituting health hazards, benefit from a specific exception: EC can be dispensed without medical prescription. Thus, paradoxically, the single-dose administration of LNG, with no medical consultation or follow-up, corresponds to 50 daily doses of an oral contraceptive that remains subject to prescription.

\section{Incapacitating pharmacists in fulfilling their mission}

Despite their professionalism and diligence, pharmacists cannot properly carry out their specific role of providing information and advice where dispensation is anonymous, precluding access to an adolescent's pharmaceutical records. Moreover, young women can refuse any dialogue and demand the medication that they are entitled to. Changing interlocutors within a single pharmacy or among various pharmacies makes it possible for repeated use of EC to go unnoticed [3-5].

\section{Unlimited entitlement}

Pharmaceutical costs are covered in the absence of any medical prescription, whereas it is precisely this official document that normally gives rise to Social security entitlement for a given period of time. With EC, a minor's demand is automatically covered financially by national solidarity [6-8].

\section{Cost-free access}

Whereas dispensation of nearly all medicinal products are partially covered by national Social security (on average up to about $30 \%$, with the highest rate of reimbursement, $65 \%$, being limited to those medications targeting serious pathologies where actual clinical benefits are the greatest) , use of EC, even repeated, is totally cost-free for minors. This liberality thus runs 
directly counter to the current public policy of strictly controlling health care costs $[9,10]$.

Given all of these exceptions, a minor is free to use EC not just on an occasional basis, but unbeknownst to her parents, physician and pharmacist, repetitively. The frequency of this offlabel use cannot be assessed in the population since anonymous dispensation precludes carrying out any drug use study [11].

In addition, the absence of any financial contribution on the part of adolescent EC users encourages consumption on a microeconomic level. Consequently, the mental representation that young women may have of these EC drugs might parallel that of innocuous consumer products.

Moreover, in terms of protecting adolescent heath, the two initial premises are not validated:

a) The hypothesis according to which the benefit-risk ratio in EC is always satisfactory, justifying its automatic use, is debatable, due to:

a. the uncertainty of the mechanisms of action of these products,

b. the low probability that EC use coincides with the few days preceding the LH surge.

b) The safety of repeated off-label use remains uncertain since the limited amount of data available is contradictory, and given the impossibility of lifting the veil of anonymity to conduct pharmaco-epidemiological studies, this uncertainty is difficult to reduce [12].

\section{The Impact on Public Health}

\section{Recourse to EC}

In 2016, more than 1.3 million packages of EC were dispensed in France. The latest data relative to free drug delivery to minors date from 2010 , reporting 362,273 packages. The only declarative data from minors, in 2010, reports that among those young women in the region of Provence-Alpes-Côte d'Azur who indicated having had at least one sexual relation, $46.1 \%$ declared having taken EC. A national survey among 15 to19-year-old girls reported a rate of $42.4 \%$ [13].

\section{The impact of greater accessibility to EC}

Given the great number of factors involved, it is impossible to isolate the impact of a program providing easier access to EC based on the rates of unwanted pregnancies and abortions in minors. It is thus unrealistic to claim the existence of any causal relationship in one direction or another. Nevertheless, some of the data available follow:

a) In France, linking data of EC consumption and the abortion rate between 2002 and 2010 reveals no correlation: the constant increase in minors' recourse to free EC (a 7 -fold increase over 8 years) cannot explain the increase in recourse to abortion up until 2006, followed by adecrease. b) On an international level, out of the 25 studies identified in 2011 assessing actions to improve access to EC, only one showed a link between EC access and a low rate of abortion in certain cohorts. According to the authors, this relative failure might result, on the one hand, from the moderate effectiveness of EC, and on the other, from unexpected consequences of the program reducing its impact. Indeed, greater accessibility to EC could bring about a behavioral modification in certain adolescents, notably an increase in risky sexual practices. Highlighting strong correlations between EC accessibility and the incidence of sexually transmitted infections, comparative studies carried out in England and the United States reinforce this hypothesis [1416].

In a universal perspective, microeconomics reflects this phenomenon: EC plays a role of extra insurance minimizing the psychological costs of unprotected sexual intercourse, and as a corollary, induces behavior that would not have occurred without such protection. Thus, the decrease in the number of pregnancies -a direct effect of EC- would be compensated for by its indirect effect, the greater frequency of at-risk sexual practices. The counterproductive effects of easier access to EC can no longer be masked $[17,18]$.

\section{Conclusion}

In France, it is urgent to address our insufficient understanding of:

a) the benefit-risk ration of EC, in particular in cases of repeated use,

b) the benefit-risk ratio of free and anonymous dispensation of EC to minors.

Specific studies should be conducted to address the numerous questions raised, in particular:

a. For young girls with free access to EC, does shortcircuiting contact with a physician not result in their receiving deficient support, lack of care and personal attention as regards their own physiology and sexuality?

b. Is it fair to dispense at no cost a drug to reduce avoidable risks when patients suffering from unavoidable serious diseases must bear a certain-sometimes non-negligible-part of their pharmaceutical costs?

c. Will this liberality lavishly offered encourage adolescents, both female and male, to take responsibility for their own body, towards their partners, and on a wider scale, on an ecological level?

d. The studies to be undertaken should call on, as appropriate, specialists of clinical pharmacology, pharmacoepidemiology, economics, education and, on a wider level, the human and social sciences. 


\section{References}

1. Articles L. 5134-1 et D. 5134-1 du code de la santé publique et suivants.

2. Taboulet F, Siranyan V (2015) La contraception d'urgence délivrée aux mineures: enjeux de sécurité et de santé publique. Revue Générale de Droit médical 2(4): 215-232.

3. Pichetti S, Sermet C (2016) La consommation de médicaments en France. In La politique du médicament. Actualité et dossier en santé publique 97: 17-22.

4. Taboulet F (2018) La contraception d'urgence chez les mineures: Une offre illimitée en manque d'évaluation. Médecine \& Droit pp 149: 31 38.

5. Taboulet F (2016) La contraception d'urgence pour les mineures: paradoxes et interrogations. Droit, santé et société Journal de Médecine légale-Droit médical 2(4): 53-65.

6. Berthouze M (2017) La contraception d'urgence chez les mineures: état des lieux de ce dispositif dérogatoire, enquête auprès des pharmaciens de Midi-Pyrénées. Thèse de Sciences pharmaceutiques. Université de Toulouse, Italy.

7. Serfaty D (2017) Evolution du marché de la contraception en France: la pilule continue de diminuer. Journald'information médicale 20(7).

8. Coutelle C, Quéré C (2015) Rapport d'information 2592, enregistré à la Présidence de l’Assemblée nationale le 18 février 2015, fait au nom de la délégation aux droits des femmes et à l'égalité des chances entre hommes et les femmes, sur le projet de loi relatif à la santé.

9. Centre Régional d'information et de Prévention du Sida PACA (2014) Données sur la contraception, la contraception d'urgence et l'IVG en France. Mai, France.
10. Vilain A (2017) 211900 interruptions volontaires de grossesse en 2016. Études et Résultats. DREES 1013.For 1,000 girls from 15 to 17 years of age, respectively, 8.4, 9.3, 11.5, 10.9 and 6.7, in 2000, 2002, 2006, 2010 and 2016

11. Girma S, Paton D (2011) The impact of emergency birth control on teen pregnancy and STIs. Journal of Health Economics 30(2): 373-380.

12. Ibid.

13. Durrance CP (2013) The effects of increased access to the morning after pill on abortion and STD rates. Economic Inquiry 51(3): 16821695.

14. Girma S, Paton D (2015) Is education the best contraception: The case of teenage pregnancy in England? Social Science \& Medicine 131: 1-9.

15. Atkins D (2014) Association between increased availability of emergency contraceptive pills and the sexual and contraceptive behaviors of women. J Public Health Policy 35(3): 292-310.

16. Gross T, Lafortune J, Low C (2014) What happens the morning after? The costs and benefits of expanding access to emergency contraception. J Policy Anal Manage 33(1): 70-93.

17. Raymond EG, Trussell J, Polis CB (2007) Population effect of increased access to emergency contraception pills: systematic review. Obstet Gynecol 109(1): 181-188.

18. Raymond EG, Trussell J, Polis CB (2013) Cost-effectiveness of increased access to emergency contraceptive pills: probably not. Contraception 87(4): $504-508$.

\section{Your next submission with Juniper Publishers will reach you the below assets}

- Quality Editorial service

- Swift Peer Review

- Reprints availability

- E-prints Service

- Manuscript Podcast for convenient understanding

- Global attainment for your research

- Manuscript accessibility in different formats

( Pdf, E-pub, Full Text, Audio)

- Unceasing customer service

Track the below URL for one-step submission https://juniperpublishers.com/online-submission.php 